\title{
Conceptual Issues in Second Language Research in Africa
}

\author{
Olushola Bamidele Are (Lokoja, Nigeria)
}

\begin{abstract}
This paper is an overview of some of the complications associated with conceptualizing second language in African societies, particularly with reference to European languages. Most popular opinions and many scholarly insights appear to define second language mainly in terms of sequence of acquisition. From this perspective, the term second language refers to a language learnt in addition to a previously acquired one. While this view of second language actually applies to many African situations, there are complex bilingual and multilingual situations in Africa that pose serious conceptual problems when viewed from the standpoint of this dominant view. This paper raises the need for scholars to be conscious of these situations, and the variations in the conception of second language that consequently exist, so that divergent perspectives of second language can be better accommodated in the emerging global academic community.
\end{abstract}

\section{Introduction}

This paper is meant to enhance conceptual accommodation among Applied Linguistics scholars in different countries with regard to the concept of Second Language (L2). In particular, it is targeted at scholars in countries whose second language (L2) scenarios are different from those of African societies. In a world in which contacts among researchers from different parts of the world are increasing rapidly, it is important for experts of the same field to understand the conceptual perspectives from where their peers in other societies are operating. In the case of the concepts of L2, such understanding is pertinent in view of the complications sometimes involved. Yet, scholars usually discuss issues relating to L2 without any effort to clarify their perspectives on the concepts. It appears as if some scholars write with an underlying assumption that the meaning of the term L2 is immediately obvious. This however is far from being so. Crystal (1997: 372-373) attests to the fact that there are differences in perspectives, ranging from views that see L2 as merely a synonym for foreign language, to those that see L2 as a non native language that has roles in areas such as education, governance and so on. The latter would not emphasize the sequence of acquisition or view L2 strictly in relation to persons who already speak their Mother Tongues (MT) but are learning to use other languages.

In Africa, the concept of L2 is a bit complex because of the peculiar linguistic profile of the continent. This needs to be highlighted for the benefit of scholars who may not be very familiar with the language situation in Africa. This paper is an attempt to make a contribution in that direction.

Although there is no doubt about the fact that these issues have previously been raised (Afolayan 1987; Crystal 1997; Kwofie 1989), there is a more urgent need for these clarifications to be re-examined now in the face of scholastic globalization and increasing interest in L2 in the West, which has so much influence in the field of Applied Linguistics.

A recent experience of this writer can serve as an anecdotal illustration of this imperative. This writer submitted a paper on second language reading to a British peer review journal. In 
the paper, an analysis of reading difficulties was made with a view to establishing appropriate pedagogical responses that would be relevant in typical second language (L2) situation. One of the many objections eventually raised by the editors was that there was a need to write about the L1 reading abilities of the subjects of the research. Obviously, the editors' view of L2 reading presupposes that the subjects in question must have L1 reading skills such that issues of L2 reading would naturally be viewed in relation to L1 reading. This conforms to the view that L2 naturally presupposes the existence of a chronological L1.

While this is true and obviously logical in many situations, it may not be true in many excolonial countries. The term L2 is widely used for ex-colonial languages despite the widely acknowledged existence of diverse kinds of L2 speakers/readers including those who cannot even communicate in local African languages. Indeed, there are situations where the language of former colonial masters may in some cases be a language learnt simultaneously with an indigenous language or even learnt before an indigenous language (Are 2010). Yet, such a language may be referred to as L2 especially from the societal and even a pedagogical perspective. This perspective may not suite the basic logic of L1/L2 discourse, but it is clear that the simple classification that hinges on sequence of acquisition will not suit some African situations.

Many speakers of ex-colonial languages in some African societies are today deemed L2 speakers of such language strictly from the societal perspective. From the individual perspective though, things may not be so straight forward especially when the sequence of acquisition is considered. This situation obviously may not manifest so strongly in less linguistically complex societies. This probably contributes to the emerging fundamental differences in perspectives, which appeared to reflect in the editors' opinion earlier referred to.

In addition to this, it will serve the interest of scholars and teachers in post colonial societies to highlight these issues at this time in order to enhance insights into required inputs into all L2 learning programs. Koda (2005: 7), writing on L2 reading (an aspect of L2 instruction) observes that "an essential first step in gaining a clear understanding of L2 reading development is to determine the particular learning characteristics of the particular group involved". This is true of all dimensions of L2 learning. The knowledge of divergences in L2 situations can enhance the required understanding. This paper could also contribute to knowledge in this wise.

\section{General Perspectives on the Concept of Second Language}

There is a traditional perspective that views L2 in relation to persons who already speak their Mother Tongues (MT) but are learning or have learnt to use other languages. This appears to be the dominant perspective. An old but still influential work like Krashen (1981) appears to rest a number of principles on this believe. For example, assertions regarding the role of L1 in L2 learning (ibd.: 64-69) are premised mainly on the notion that there must be an existing L1 before one can talk of an L2. Also, more recent works like Cook (1995: 5) defines L2 as "all learning of languages other than the first in whatever situation or for whatever purpose". The underlying assumption becomes clear when Cook claims that "people learning a second language already know how to mean" (ibd.: 6). Very significantly, he cites UNESCO's definition which says that an L2 is "any language acquired by a person in addition to his/her mother tongue" (the language learnt first as a child) (ibd.: 6).

Web definitions of L2 are based on this perspective. For example, the famous site, Wikipedia defines it as "any language learned after the first language or mother tongue", while answers supplied by contributors on the Yahoo Answers discussion forum also follow this perspective. These are significant as they represent some of the first sources of choice for information/knowledge seekers in this IT age. 
On a general theoretical note, the use of the word 'second' simply presupposes that there is a 'first'. This is to say that when a person is said to learn or use an L2, it is assumed that such a person has acquired one language already and is only adding a second one. As stated earlier, this assumption is very valid for many L2 users of different languages all over the world. Indeed, many speakers of European languages in Africa still fit this perspective, as contact with the European languages often take place in schools after the people in question have already acquired their Mother Tongues (MT). This perspective also defines the situation of many immigrants learning to use the languages of their host communities. This latter scenario is particularly very relevant to Western societies where immigration has been phenomenal in recent years. As the waves of immigration into the West continue, Western societies have seen mass immigration of people needing to learn the hosts' language in addition to their native languages. Indeed, current renewed interest in L2 could be a result of this situation. In this regard, Avalos (2003: 202) opines (with respect to the USA) that "as the population of the United States becomes more and more diversified ethnically and racially, educators' concerns for addressing the needs of second language learners have also increased. With this has come a renewed interest in second language reading processes".

Against this background, it is not surprising that views of L2 that emphasize prior ability to use a MT are so dominant in popular opinion and in scholarship. Yet, the point must be made that with increasing cultural and linguistic mix, L2 configurations in the world are fast changing. In Western Europe for example, many immigrant minority (IM) languages of nonEuropean origin and some of Eastern European origin are being added to the linguistic map, thereby further complicating some situations where many people already combine the knowledge of regional minority (RM) languages such as Welsh, Basque, Frisian, Gaelic, Saami, Limgurgian, Welsh and so on with majority languages (Extra/Yagmur 2002). Also, the continuing spread and entrenchment of English is complicating the European linguistic landscape by producing new generations of speakers of English as a L2 (Philipson 2004; Archibugi 2009). Other forms of L2 situations in Western societies are exemplified by the existence of heritage language learners - an issue discussed extensively in Valdes (2005). These are people learning to use the language of their ancestry in addition to the dominant language of the immediate environment, after acquiring a certain degree of competence in the ancestral language at childhood. The heritage language learners' situation does not fit some of the basic assumptions of the traditional view of L2. The application of terms to these people is, in the words of Valdes (2005: 415), "neither simple, obvious nor straight forward".

The implication of all these is that the processes of acquisition of learning may be becoming less straight forward; such that a view of L2 that is based on the chronology of acquisition may now require some clarification in some complex sociolinguistic contexts.

Such complexities are not uncommon in and Asia and Africa where societies have always been very multilingual. Interestingly, in a discussion of L1/L2 complexities and the implications for perspectives on concepts, Valdes (2005: 414) mentions the complex situations of Asia. Valdes refers particularly to a Singaporean scenario where a child uses Chinese at home, English in school, Malay in the market place, and English and Malay among his peers. The peculiar case of Africa, which is the focus of this paper, is discussed extensively in the next section of this paper.

\section{The Second Language Situation in Africa}

Africa is a baffling mosaic of complex linguistic configurations. The number of languages on the continent and the way they are distributed present unique situations which in many cases are yet to be fully understood by scholars. It has been estimated that there are about 2,582 languages and 1,382 dialects in Africa (Lohdi 1993: 79). Gadelii (2004) citing Ethnologue (1996) points out that sub-Saharan Africa alone has $30 \%$ of the world's languages. Many of 
these languages have been in contact for centuries, such that bilingualism and multilingualism have been familiar features of the lives of Africans. One of the essential issues recognized at the Harare Conference of 1997 is the fact that Africa has had a long tradition of multilingualism which has been very functional in most speech communities (Chimhundu 2002: 4). The Harare report, like Gadelii (2004), Lohdi (1993), and Trudell (2009) recognizes the complex system of languages whereby different ethnic and linguistic groups are in contact via languages of contact that often are the bigger languages (in terms of numbers of speakers). The implication of this was that being either bilingual or multilingual was the norm rather than the exception for millions on the continent.

The language situation in Africa was further complicated by the advent of colonialism and the inevitable addition of European languages to the different linguistic scenarios on the continent. It may be necessary to make a brief review of the dynamics involved in the entrenchment of European languages, and the implications for how they function as important L2s in different African societies regardless of the colonial heritage (British, French, Spanish or Portuguese).

Obayan (1996) provides an overview of how the imposition of European languages occurred in different African countries principally through education. The system of imposition depended on the colonial policies of the European countries involved. Countries colonized by the French taught the French language at all levels and from the first day in school. Also, countries colonized by the Spanish and the Portuguese had a practice very similar to that of the French. On the other hand countries colonized by the British taught English at all levels, but always made sure that the first years of formal education were conducted in the L1 of learners or in the language of their immediate environment. Similarly, countries colonized by the Germans, while seriously promoting the German language, also gave prominence to indigenous languages in the early years of schooling.

In addition to these, Obayan (1996) identifies other subtle policy differences. The French tried more than other colonial powers to assimilate their African subjects linguistically and culturally. The British, for example, were "said not to be too keen on perpetuating 'EnglishEnglish' in Africa".

Obviously, the French were not so liberal. According to Obayan (1996) "the French were [...] said to be more intolerant of 'strange' accents and deviations in usage. Schools in the French colonies therefore made strenuous efforts to teach 'French-French', in terms of both accent, and usage in general". Obayan (1996) observes that although there is no empirical evidence to support it, it is often said that French colonial policy ensured a high degree of mastery of French in the French colonies than English. For countries colonized by the Spanish and the Portuguese (whose policies resembled that of the French), one may add too that there is no evidence of any significant higher degree of mastery of these languages among the African populations. What is clear is that the process of the entrenchment of European languages began principally via education, and has continued till date.

At independence, efforts were made in all African countries towards domesticating the educational system inherited from colonialism. In this regard, the need to promote indigenous languages was high on the agenda. Different language policies were worked out over the years to "give African languages elbow room in relation to foreign languages" (Chimhundu 2004: 10). Though a lot was achieved in this regard, European languages remain the major languages of education and governance. Gadelii (2004: 8f.) reveals that out of the thousands of languages on the continent, only about 24 enjoy official language status, and even then they function in this capacity along with European languages. The exception to this is Madagascar where Malgache is listed as the only official language. 
The European languages consequently acquired 'superior' status as they became the languages of the educated rich elite. They have largely maintained this status in the face of reluctance of many African Countries to replace them as official languages for fear of possible political backlash. Also, many governments are aware of the social and economic value of European languages and are struggling to balance this with the promotion of local languages, as Granville et al. (1998) observe.

Many of the local languages consequently sank in status and became the languages of the 'commoners' as exemplified in a study like Are (1998) which investigated choice of language of literacy in Nigeria, and confirmed a strong preference for English, even where the choice of the learners' own ancestral languages were available. Also, Lawal (1995) observes this trend in a research situation among secondary school pupils. He attributes it to government policy which has made the ex-colonial languages the languages of the powerful and influential while making the local languages the languages of the powerless and dispossessed.

The implication of this situation was that while many Africans already had second, third, fourth (or more) languages, the colonial languages were added to the fray and became the high priced target of those who wished to acquire education and elite status. People had to learn a European language if they have to acquire education and join the upper echelons of society.

The fate of the local languages appears to remain largely the same today with the exception of some successes in the use of Swahili in some East African countries (Lodhi 1993:2). In some other places like Ghana, use of indigenous languages has actually suffered official reverses with the 2002 policy of using English as sole language of instruction at all levels of education (Owu-Ewie 2006: 77).

In the early days of colonialism, schools provided the first contacts with the colonialists' language. Things are however changing with the colonial (now ex-colonial) languages becoming very present in different social situations (including some homes), such that local varieties of these languages have emerged and are increasingly been encountered and acquired outside the school system. The situation in Nigeria is well documented in the works of such scholars as Banjo (1971), Odumuh (1981) and Onochie (1997). Indeed, Kwofie (1989: 26) argues that in some parts of Africa, "educated African parents consider it advantageous for their children to acquire such autochthonous languages first before they learn their Mother Tongues" or the indigenous languages. He goes on to point out an increasingly noticeable situation whereby "children may grow up speaking as their first language a language which is not the MT of any of the parents" (ibd.). According to him, in educated homes, this language often turns out to be a European language. He is quick to add, though, that this situation remains "inconceivable" in uneducated home. Today, twenty two years after the publication of Kwofie's study, one can safely conclude that there is likely to be more of such people now because the dynamics that produce this situation- urbanization and education- have been on the increase in Africa.

Unfortunately, very little has been done in Africa to obtain specific data regarding the people in this category. A website, nationmaster.com, which display statistic of nations claims that in Liberia, for example, $20 \%$ of the people use English as their chronological L1. This site also claims that out of the 41 million Nigerian who speak English, one million learnt it as their chronological L1. These figures are difficult to ascertain. For example, the figure for the number of Nigerians who, according to this site, use English as a chronological L1 is likely to be a gross under-estimation. These figures prove, though, that the phenomenon of learning European languages naturally from the immediate environment is real. This may involve speaking the European language before learning to speak an African language, or learning the two simultaneously. It may even involve being able to use only a European language. 
From the foregoing, it is immediately obvious that the linguistic configurations involving European languages in Africa may (as in some other parts of the world) not always be amenable to description within the framework of a view of L2 that is based on sequentiality. Gransville et al. (1997: 25), writing about the South African situation explain that the term L2 in this sense can be "problematic in a multilingual society in which children begin to acquire two or more languages from the earliest childhood". In addition, the term carries some "pejorative overtones" which associates it with "second rate" Gransville et al. (ibd.). They further ague that any other terms associated with acquisition/learning sequence, such as L1, MT and so on, can be problematic in a typical African context if not properly clarified. According to them:

---the terms are problematic in a multilingual society for several reasons. Firstly many children begin to acquire more than one language from their earliest childhood so that they do not have one first or native (in the sense of original) or home language. Secondly, for some people, the language(s) that they acquire first do not continue to be the language(s) in which they are most competent as adult or which they feel most comfortable using. Thirdly, the main languages of the family may be the language(s) of the languages of the community where the family lives and not the language(s) of the mother.

These situations must be factored into conceptions of what L2 means in Africa. An attempt is made to do this in relation to ex-colonial (European) languages used as L2 on the continent.

\section{Conceptualizing European Languages as L2 in Africa}

In order to properly conceptualize European languages as L2 in the kind of situation described above, it may be necessary to give an overview of some of the essential assumptions of the traditional perspective on L2, and subsequently explain in a systematic way, why they may be problematic if adopted wholesale for the African context. Some of these traditional assumptions reflect strongly in the analysis made in Yule (1996) in his attempt to differentiate between an L1 and an L2 learning situations. Yule agues that:

- L1 is acquired naturally at childhood while L2 is learnt later.

- Learning an L1 is an unconscious process, while learning an L2 is a conscious process.

- L1 involves total mastery while L2 use may not involve total mastery.

- $\mathrm{L} 1$ is picked from the immediate environment while L2 may not be picked from the immediate environment.

- L1 is not prone to affective filters (factors of affect that inhibit learning) while 2 is.

In Africa as well as other former Colonial territories, the view of what L2 means cannot be so simple (as previously pointed out in this article). Indeed, the role ex-colonial languages and their mode of acquisition carry an imposing array of complexities which make the very definition of L2 quite tasking.

The first point raised by Yule (the assumption that an L2 is learnt later), may not apply to many Africans whom we still consider as L2 speakers of ex-colonial languages. There are indeed a substantial number of people who acquire an African variety of English at childhood via the natural process of language acquisition. The question that arises from this is: can we categorize ex-colonial languages in the context of such people as a L1, especially in the case of reverse asymmetrical bilinguals who may even acquire an ex-colonial language first, and learn an African language later? This question is further complicated by the more familiar situation of people who acquire both the ex-colonial language (albeit an Africanized variety) along with an African language simultaneously. There are important reasons why it might not 
serve our academic and pedagogical purposes to view all such people as L1 users of the excolonial languages. Such reasons will be given at an appropriate point in this paper.

The second point raised by Yule has to do with factor of conscious versus unconscious learning. The general assumption here is that unconscious learning characterizes L1 situations while conscious learning characterizes L2 situations. Of course, this is not the case for many African children who have learnt to use ex-colonial languages. Many now learn both the excolonial language and their local languages unconsciously.

The assumption that total mastery characterizes L1 while that is not the cases with L2 also poses a problem. The reality of some African children is that they lack total mastery of both the ex-colonial language and their African Languages, such that some (especially in some elitist set ups) may actually be quite incompetent in their African languages. Although total mastery is often lacking in even those who acquire the ex-colonial languages normally, it is (in this case) not a function of the use of a previously acquired language.

In addition to the above, the assumption that L2 is NOT usually picked from the learner's immediate environment raises questions about the status of ex-colonial languages among some categories of people in Africa and other ex-colonial territories. There are emerging contexts in these countries where certain local varieties of the ex-colonial language may actually be more available for some children than local African languages (Kwofie 1989). Children of educated people growing up in environments that are highly culturally and linguistically diffused are in this category.

Finally, Yule assumes, in accordance with the traditional view, that affective filters affect only L2 learning. The reality is that this is simply not true in all cases in our own context. In contexts where people ignorantly attach a status symbol to the use of ex-colonial languages in homes, affective filters actually work negatively against the acquisition of local languages among the children involved.

The above clearly suggests that scholars in the African context and some other post colonial societies must be applying a perspective of L2 that transcends the ordinary connotation of the term "second". This is why they continue to refer to the ex-colonial languages as L2.

In a landmark contribution based on the Nigerian situation where English is the ex-colonial language in use, Afolayan (1987) identifies a number of different linguistic scenarios in which the term English as Second Language (ESL) would apply. This of course includes a scenario similar to the one Yule identfies, but it, necessarily, includes other scenarios. In the view of Afolayan ESL may refer to English when it operates in the following ways:

- It may or may not be the sequentially second language of a bi-or multilingual person.

- A language in which a bi-or multilingual conducts his daily routines in conjunction with another language in which the person is more competent.

- The language which has the socio-cultural function of "serving as an instrument of forcing bilingualism or biculturalism on its user country or community, usually of exColonial peoples... and turning such community into a special speech community of that language" (13).

The essential issue to note from the above criteria is that accommodation is made for diverse situations in the determination of what an L2 is. This of course includes the case of a language that is sequentially an L2. It must be reiterated that when the term L2 is used in the African context (as well as in many other post colonial countries) a broader perspective such as this is often implicitly intended even if not explicitly stated. This perhaps is principally because, regardless of sequence of acquisition and other features, the overwhelming proportion of L2 
speakers of ex-colonial languages shares some common characteristics which have pedagogical and communicative significance. They include:

- exposure to inadequate or inappropriate data of the target language,

- coloration of usage by socio-cultural and environmental peculiarities in line with what Malinowski (1935, cited in Olateju 1998: 2) called "context of culture and the context of situation,"

- the consequent emergence of variant forms,

- possession of a limited repertoire of vocabulary (Muodumogu 1999),

- tendency to depend on written texts for appropriate and adequate data of the

- target language (Are 2010), and

- inability, on the part of many, to become fully functional readers in target language texts (Unoh 1980; Onochie 1985; Are 2010).

The case being made here is that regardless of individual differences in sequence of acquisition (Kwofie 1989; Gransville et al. 1997), and the subtle or major differences these may have on learning, the points listed above are characteristic features of different types of L2 speakers in these ex-colonial languages in Africa which have been observed in communicative and pedagogical contexts. Therefore, there is a the tendency to refer freely to English in Nigeria and South Africa, French in Togo, and Portuguese in Angola as second languages regardless of order of acquisition, level of competence or even frequency and context of use among different segments of the population. The use of the term this way, albeit without being formally defined, governs the views of Chimhundu (2002); Olateju (1998); Owu-Ewie (2006); Schlebusch and Thobedi (2004). The view also manifests where it is defined and elaborated like in Akindele and Adegbite (1999).

In addition to this, the European languages in Africa, remain dominant only largely in the spheres to education, commerce, governance and the media. The majority of the people still use local languages in daily interpersonal communication. This means that from the perspective of overall frequency of daily use, the local languages still rank "first", leaving the European languages in "second" position. From the societal angle therefore, these languages remain second.

One must note that it is not uncommon to find references to European languages as L1 in contexts where individual bilingualism is discussed as exemplified by a citation from Kwofie (1989) earlier made in this paper. This not withstanding, the tendency described here appear to be the most dominant, though, as emphasized before, very seldom clearly articulated. As a matter of fact not very many scholarly works have been devoted exclusively to this conceptual issue, though, as this paper has shown, it has surfaced severally in the works of African scholars. This is an open field for fresh insights.

There is a possibility that the tendency not to provide the necessary clarifications may have practical disadvantages in many African societies where efforts are not usually made to sensitize the language teacher to the implications of each learner's L2 situation. Yet, such factors are believed to be crucially important in learning situations. For example, the pace at which a person can learn to read L2 texts may be determined to a large extent by whether or not the person already has oral skills in the language, as well as the extent of such oral skills. This may vary depending on L2 situation (i.e. whether the individual has acquired the language before coming to school or is having contact with the language for the first time in school). Avalos (2003:172), points out that "oral language proficiency is commonly used by 
teachers to make instructional decisions and used as a readiness indicator for program placement or to transition students to ...". A poorly trained instructor may unconsciously adopt a whole group model approach to teaching. Yet "a generic processor or whole group model of instruction is inadequate in meeting L2 readers' needs because it assumes that all students are the same" (Avalos 2003: 171). It must be said though that there are yet no convincing studies to clearly prove the operation of this factor in the African context. There is therefore room for more research in this area.

\section{Conclusion}

One must reiterate the fact that this work is simply intended to offer some clarifications regarding the conceptualization of L2 in Africa. Essentially, the paper has agued that while a view of L2 that is based on sequence of acquisition is very logical, valid and relevant in many contexts, the global community of linguists must not lose sight of the existence of diverse views of what L2 means, especially within the context of international interactions. Also, one must stress the fact that this writer, does not pretend that the views expressed here are necessarily novel. This has been emphatically demonstrated in the body of this work. They are simply presented here to meet a perceived need of our time. The crux of the matter is that when scholars from Africa or some other post colonial society use the term L2, they are referring more to the role of the language in question and not the sequence of acquisition. The issue is not to say that one view of L2 is right while others are wrong. Usage of words and terms are, as most people know, dynamic, such that room must be made for conceptual variations in academic discourse. Beyond this, the need for research into the pedagogical implications of the existence of different L2 situations within some communities in Africa must also be emphasized.

\section{References}

Afolayan, Aadebisi (1987): "English as a Second Language: A variety or a Myth". Journal of English as a second Language (JESEL) 1: 4-14.

Archibugi, Daniele (2009): Which Language for Europe? http://www.opendemocracy.net /printpdf/48168, accessed February 19, 2011.

Akindele, Femi/Adegbite, Wale (1999): The Sociology and Politics of English Language in Nigeria. Ife: Obafemi Awolowo University Press.

Are, Olushola Bamidele (1998): Language Attitudes and Literacy Function among Participants in a Literacy Program in Nigeria. Unpublished MA Thesis, University of Ilorin, Nigeria.

Are, Olushola Bamidele (2010): Relationships between Reading Competence and Interest in Reading in the Nigerian ESL Context: A Study of Lokoja Metropolis. Unpublished PhD Thesis, University of Abuja, Nigeria.

Avalos, Mary A. (2003): "Effective Second Language (Literacy) Reading Transition: from Learner Specific to Generic Instructional Models". Bilingual Research Journal 27/2: 171206.

Chimhundu, Herbert (2002): Language Policies in Africa. Report of the Inter Governmental conference on Language policy in Africa Held I Harare, Zimbabwe, 17-21 March, 1997. UNESCO. http://www.unesco.org/../00245-EN.pdf, accessed July 26, 2009.

Cook, Vivian (1991): Second Language Learning and Language Teaching. London: Edward Arnold.

Crystal, David (1997): Cambridge Encyclopedia of Language. Cambridge: Cambridge University Press.

Extra, Guus/Yagmur, Kutlay (2002): Language Diversity in Multilingual Europe: Comparative Perspectives on Immigrant Minority Languages at Home and at School. Paris: UNESCO M.O.S.T Program. 
Gadelii, Karl E. (2004): Annotated Statistics of Linguistics Policies and Practices in Africa. http://www.ipd.gu.se/digitalAssets/1310/1310354_annotated-statistics.pdf, accessed February 19, 2011.

Gransville, S. et al. (1998): English With or Without Guilt: A position Paper on Language in Education Policy for South Africa. Johannesburg: University of the Witwatersrand.

Koda, Keiko (2005): Insights into Second Language Reading: Cambridge: Cambridge University Press.

Krashen, Stephen D. (1981): Second Language Acquisition and Second Language Learning. California: Pergamon Press Inc.

Kwofie, Emmanuel (1989): The Acquisition and Use of French as a Second Language in Africa: Sociological, Historical-Comparative and Methodological Perspectives. http://www.eric.ed.gov/ERICWebPortal/recordDetail?accno=ED313908, accessed February 19, 2011.

Lodhi, Abdulaziz Y. (1993): "The Language Situation in Africa". Nordic Journal of African Studies 2/1: 79-86. http://www.njas.helsinki.fi/pdf-files/vol2num1/lodhi.pdf, accessed July 26, 2009.

Lawal, Adebayo (1995): "Language Skills and National Curriculum Development in Nigeria: Policy, Process and Product". In: Woods, Paul (ed.) (1995): Language skills in National Development. Manchester: British Council.

Muodumogu, Chinwe A. (1999): "Two Methods of Vocabulary Instruction at the Senior Secondary School Level". Nigeria Educational Forum 15/1: 43-47.

Obayan, Pai (1998): "Language Education in Africa: Lessons for and From Nigeria". Fafunwa Foundation Internet Journal of Education. http://fafunwafoundation.tripod.com/ fafunwafoundation/id7.html, accessed February 19, 2011.

Odumuh, Adama E. (1987): Nigerian English. Zaria: Ahmadu Bello University Press.

Olateju, Moji A. (1998): Discourse Analysis: Analyzing Discourse in the ESL Classroom. Lagos: Cross Land Educational Services.

Onochie, Ernest O. (1985): "Readability Assessment in Second Language: A comparative Study of the Cloze Procedure and the Fry Formula". Literacy and Reading in Nigeria 3: 217-243.

Onochie, Ernest O. (1997): "Personal Communication in Nigerian English". Journal of English as a Second Language 4: 21-43.

Owu- Ewie, Charles (2006): "The Language Policy of Education in Ghana: A Critical Look at the English-Only Language Educational Policy". In: Mugane, John et al. (eds.) (2006): Selected Proceedings of the $35^{\text {th }}$ Annual Conference on African Linguistics. Summerville/MA, Cascadilla Proceedings Project: 76-78.

Philipson, Robert (2004): "If Language Policy Issues are Explosive, How should they Best be Handled?". Paper Presented at the $2^{\text {nd }}$ Mercator International Symposium, TarragonaCatalyuna. http://www.ciemen.org/mercator/pdf/simp-phillipson.pdf, accessed February 19, 2011.

Schlebusch, Gawie/Thobedi, Motsamai (2004): "Outcome- Based Education in the English Second Language Classroom in South Africa". The Qualitative Report 19/1: 35-48. http://www.nova.edu/ssss/QR/QR9-1/Schlebusch.pdf, accessed July 26, 2009.

"Second Language" (2012). http://en.wikipedia.org/wiki/Second_language, accessed August $10,2012$.

Unoh, Solomon. O. (1980): "The Reading Problems in Secondary School: Some Observation and Research Findings". Journal of Language Arts and Communication 1/1: 30-40.

Valdes, Guadalupe (2005): "Bilingualism, Heritage Language Learners, and SLA Research: Opportunities Lost or Seized?". The Modern Language Journal 89/3: 410-426.

Yule, George (1996): The Study of Language. Cambridge: Cambridge University Press. 